\title{
Epidemiological survey of the taeniasis/cysticercosis complex in cattle farms in Viçosa County, Minas Gerais, Brazil ${ }^{1}$
}

\author{
Tatiane O. Santos ${ }^{2 *}$, Paulo S.A. Pinto ${ }^{2}$, Adriana F. Iasbik ${ }^{3}$, Letícia F. Silva², Emílio C.A. Nieto² \\ and Rafaella P.M. Guimarães-Peixoto ${ }^{2}$
}

\begin{abstract}
Santos T.O., Pinto P.S.A., Iasbik A.F., Silva L.F., Nieto E.C.A. \& Guimarães-Peixoto R.P.M. 2013. Epidemiological survey of the taeniasis/cysticercosis complex in cattle farms in Viçosa County, Minas Gerais, Brazil. Pesquisa Veterinária Brasileira 33(4):449452. Laboratório de Inspeção de Produtos de Origem Animal, Departamento de Veterinária, Universidade Federal de Viçosa, Avenida P.H. Rolfs, s/n, Viçosa, MG 36570-000, Brazil. E-mail: tatyvetoli@hotmail.com

Despite the importance of human taeniasis/bovine cysticercosis for public and animal health and the economy, its actual epidemiological status in Brazil is not well-studied. We sought to assess the epidemiological profile of this zoonosis in the rural area of Viçosa County, Minas Gerais, Brazil. The prevalence of bovine cysticercosis was $0.42 \%$, whereas no case of human taeniasis was diagnosed. Factors favoring the persistence of zoonosis were identified. These included the supply of untreated water to animals, animals raised for slaughter without sanitary supervision, poor mechanization of raising techniques, and the use of untreated water for human consumption. Bovine meat for human consumption acquired in the city or from the farm itself was characterized as a risk factor for bovine cysticercosis (Odds Ratio (OR) $=16.77 ; \mathrm{p}<0.05$ ). Nevertheless, the families on the investigated farms did apply several appropriate measures to control this disease, such as the virtual lack of open sewers and the consumption of well-cooked meat. The presence of bovine cysticercosis cases, and the factors favoring its persistence, point to the need for constant epidemiological and sanitary surveillance in this county.
\end{abstract}

INDEX TERMS: Taenia saginata, Cysticercus bovis, taeniasis, cysticercosis, epidemiology, ELISA, prevalence, zoonosis, risk factors.

RESUMO.- [Inquérito epidemiológico sobre o complexo teníase-cisticercose bovina no município de Viçosa, Minas Gerais.] Apesar da importância do complexo teníase-cisticercose bovina para a saúde pública, animal e para a economia, a realidade epidemiológica da ocorrência dessas zoonoses no Brasil é pouco conhecida. Este estudo foi realizado com o objetivo de avaliar o perfil epidemiológico desta zoonose na zona rural do município de Viçosa, MG. A prevalência encontrada de cisticercose bovina foi de $0,42 \%$, e nenhum caso de teníase humana foi diagnosticado. Foi ve-

\footnotetext{
${ }^{1}$ Received on February 2, 2013.

Accepted for publication on February 21, 2013.

${ }^{2}$ Laboratório de Inspeção de Produtos de Origem Animal, Departamento de Veterinária, Universidade Federal de Viçosa (UFV), Avenida Peter Henry Rolfs s/n, Viçosa, MG 36570-000, Brazil. *Corresponding author: tatyvetoli@hotmail.com

${ }^{3}$ Instituto Mineiro de Agropecuária (IMA), Vila Gianetti, casa 35, Campus Universitário, UFV, Viçosa, MG 36570-000, Brazil.
}

rificada presença de fatores favoráveis a manutenção dessa zoonose, como fornecimento de água sem tratar aos animais, criação de animais destinados ao abate sem inspeção sanitária, criação de bovinos com baixa adoção de tecnologia, e utilização de água sem tratamento. 0 consumo de carne bovina oriunda da propriedade e da cidade foi caracterizado como variável de risco $(\mathrm{OR}=16,77 ; \mathrm{p}<0,05)$ para a cisticercose bovina. Apesar disso, as famílias das propriedades pesquisadas possuíam hábitos favoráveis como medida de controle para o desenvolvimento desta parasitose, como a quase ausência de esgoto a céu aberto e a ingestão de carne bovina bem passada. A presença de caso de cisticercose bovina e de fatores considerados favoráveis a manutenção dessa parasitose, mostra a necessidade da contínua vigilância epidemiológica e sanitária neste município.

TERMOS DE INDEXAÇÃO: Taenia saginata, Cysticercus bovis, teníase, cisticercose, epidemiologia veterinária, ELISA, prevalência, zoonose, fatores de risco. 


\section{INTRODUCTION}

The taeniasis/cysticercosis complex is a zoonosis caused by the presence of adult Taenia saginata in the small intestines of humans and the larval form of Cysticercus bovis in the tissues of the intermediate host, namely, bovines (Silva 2005). This zoonotic complex has a major impact on animal and human health and may eventually result in a serious public and animal health problem in several parts of the world, particularly in Latin America, Africa, and Asia, where it is endemic (Flisser et al. 1991).

Although taeniasis and bovine cysticercosis are found across Brazil, they occur more frequently in poorer areas associated with impoverished economic, social, personal, and environmental conditions. These areas also frequently lack proper systems for raising livestock, slaughtering conditions, and the appropriate sanitary supervision of slaughtered animals. The features that favor the transmission and persistence of this zoonosis in Brazil have been identified in both urban and rural settings (Almeida et al. 2002, Silva \& Silva 2007).

According to Souza et al. (2007), monetary losses due to bovine cysticercosis might reach U\$25.00 per infected animal. Santos et al. (2008) simulated the economic losses due to bovine cysticercosis based on the prices established by the slaughterhouse where their study was performed. They determined that from a total of U\$121,326.38, which corresponded to the total number of cattle slaughtered, $31.53 \%$ of the revenue was lost due to cysticercosis (U\$ $1.00=\mathrm{R} \$ 1.77$ according to Junior (2008)).

Despite the impact of taeniasis and cysticercosis on public and animal health and the economy, the actual epidemiological status of their occurrence in Brazil is unknown. This is due to the fact that human taeniasis does not require compulsory notification and because of the limited scope of meat surveillance in the country (Almeida et al. 2002, Agapejev 2003). Few epidemiological studies on this zoonosis have been performed in Brazil; however, its reported prevalence can be estimated from the data supplied by meat inspection records.

The present study sought to assess the epidemiological profile of the taeniasis/cysticercosis complex in the rural area of Viçosa County, Minas Gerais, Brazil, by estimating the prevalence of bovine cysticercosis and human taeniasis in rural cattle farms as a function of risk factors dependent on sanitary and socioeconomic conditions.

\section{MATERIALS AND METHODS}

The present study was performed in 2009 in Viçosa County, which is located in the Forest Area of Minas Gerais at an altitude of $648 \mathrm{~m}$, latitude of $20^{\circ} 45^{\prime} 14^{\prime \prime} \mathrm{S}$, and longitude of $42^{\circ}-52^{\prime} 55^{\prime \prime} \mathrm{W}$. The population of Viçosa County is estimated to be 74,607: 69,253 $(92.6 \%)$ reside in urban areas and 5,354 (7.2\%) in rural areas (IBGE 2006). The rural area comprises 52 communities, 45 of which were sampled in the present study.

The following parameters were used to calculate the number of farms to select for this study: a 1\% estimated prevalence of the investigated disease with $1 \%$ absolute precision and a $5 \%$ confidence interval (Epi Info, version 3.5.1, WHO, 2008). Consequently, the present cross-sectional study investigated 176 farms that were selected by simple random sampling using the lottery method.

A questionnaire with both open and closed questions was administered to the 176 families on the sampled farms to collect data on possible risk factors for human taeniasis/bovine cysticercosis, including sanitary conditions regarding raising livestock, personal hygiene, nutrition patterns, and human and animal facilities. From the selected farms only ninety raised cattle. A total of 240 bovine blood samples were collected from animals older than five months. On the same day that the blood samples were collected by jugular venipuncture, they were first incubated at room temperature to allow for serum separation and then stored at $-20^{\circ} \mathrm{C}$. Serologic diagnosis of animal cysticercosis included a first-stage screening using an indirect ELISA. For further confirmation, the suspected cases were subjected to Immunoblot analysis according to the methods previously described by Pinto et al. (2000), Pinto et al. (2001), and Monteiro et al. (2006).

Samples of human feces were collected from participants who signed an informed consent form. A labeled flask containing MIF (merthiolate-iodine-formaldehyde) was provided to participants along with instructions on how to collect and store the fecal samples. A total of 266 samples were collected from 142 farms. Parasitological diagnosis was established by investigating for intestinal parasite eggs using Hoffman's method (Silva 2005).

The questionnaire data and laboratory results were entered into the Epi Info version 3.5.1 software database (WHO 2008). The data were then used to analyze the investigated variables. The mean of the quantitative variables, the frequency of estimated variables, and the prevalence of cysticercosis were each calculated. The association between the prevalence of bovine cysticercosis and the categorical variables supplied by the questionnaire was investigated using either the Chi-square $\left(\chi^{2}\right)$ test or Fisher's exact test as necessary. The criterion to select the variables was that the raw $\mathrm{OR}$ of $\mathrm{p}<0.20$ be statistically equal to 1.00 . Multivariate logistic regression using backward analysis was performed on the significant factors using SPSS software, version 17.0 (Chicago, IL, USA). The power of association between dependent and independent variables was estimated by the OR derived directly from the logistic regression estimations; significance was established at $\mathrm{p}$ $<0.05$.

The present study was approved by the Animal Research Ethics Committee (Proc.047-2007) and the Human Research Ethics Committee (Process 074-2007) of Viçosa Federal University.

\section{RESULTS}

Among the 90 bovine raising farms, bovine cysticercosis was suspected in five (5.5\%) because six $(2.5 \%)$ out of 240 bovine serum samples tested positive using the indirect ELISA test. These farms were located in the rural communities of Duas Barras, Pinhão, Santa Tereza, Varginha, and Zig-Zag. However, cysticercosis was confirmed at only one farm $(1.1 \%)$ where one single animal tested positive based on an Immunoblot analysis. Therefore, the prevalence of bovine cysticercosis in Viçosa County was $0.42 \%$. The parasitological investigation of 226 feces samples collected from the sampled farms' residents was negative for taeniasis; however, 106 samples tested positive for other intestinal parasites, which corresponded to $43.6 \%$ prevalence.

The analysis of the applied questionnaire determined that the families at the cysticercosis-suspected farms were rural workers who permanently lived on these farms 
(100\%). The monthly family income was minimum wage ( $\mathrm{R} \$ 465.00$ ) in $40 \%$ of the families and up to twice the minimum wage in $60 \%$ of the families. On average, these families comprised two people, and that $60 \%$ this comprised three people.

In all of the farms suspected to have bovine cysticercosis, the animals were supplied with untreated water, and four farms (60\%) supplied mine/spring water to the animals. In $80 \%$ of the farms suspected to have bovine cysticercosis, untreated sewage was drained into a river or stream. None of the farms suspected to have bovine cysticercosis had open sewers; however, one farm with no case of animal disease had an open sewer. Approximately $92 \%$ of all farms drained sewage into a river or stream. The rural community of "Duas Barras" had the one animal that tested positive based on an Immunoblot analysis. This farm drained its sewage into a river/stream and supplied untreated mine/spring water to the animals.

All interviewees at the farms suspected to have bovine cysticercosis reported to know about the disease, which is colloquially known as "canjiquinha" (corn grits) or "pipoca" (popcorn). Only one interviewee reported to have never seen parasitic cysts. The residents of every farm reported consumption of bovine meat; $40 \%$ purchased their meat at city stores, and $60 \%$ consumed meat both purchased in the city and produced at the farm. Only the residents from one of the cysticercosis-suspected farms reported eating rare meat.

Because the Immunoblot analysis reveal only one positive case of bovine cysticercosis, a risk analysis was performed on the positive indirect ELISA cases. Among the variables exhibiting a $\mathrm{p}<0.020$ (Table 1 ), and thus selected for logistic regression analysis, only the consumption of meat from the city and the farm was significant (adjusted $\mathrm{OR}=16.77$; $\mathrm{p}=0.003$; confidence interval: 2.53-111.31).

Table 1. Raw odds ratio analysis of the association among possible risk factors for the transmission of bovine cysticercosis in the rural area of Viçosa county, MG, in 2009 using an indirect ELISA as the diagnostic method

\begin{tabular}{|c|c|c|c|}
\hline Risk factors & $\begin{array}{l}\text { Raw odds } \\
\text { ratio (OR) }\end{array}$ & $\mathrm{p}$-value & $\begin{array}{c}\text { Confidence } \\
\text { interval } \\
(95 \% \mathrm{CI})^{*}\end{array}$ \\
\hline \multicolumn{4}{|c|}{ Source of water supplied to animals: } \\
\hline Well & 1.00 & - & - \\
\hline Cistern & 1.67 & 0.63 & $0.00-71.62$ \\
\hline \multicolumn{4}{|c|}{ Source of water for human consumption: } \\
\hline Well & 1.00 & - & - \\
\hline Cistern & 0.64 & 0.42 & $0.02-10.22$ \\
\hline \multicolumn{4}{|c|}{ Source of water to irrigate the vegetable garden: } \\
\hline Well & 1.00 & - & - \\
\hline Cistern & 0.83 & 0.69 & $0.03-14.94$ \\
\hline \multicolumn{4}{|c|}{ Thermal treatment of bovine meat for consumption: } \\
\hline Well-done & 1.00 & - & \\
\hline Rare & 1.23 & 0.61 & $0.07-42.78$ \\
\hline \multicolumn{4}{|c|}{ Origin of meat consumed by families: } \\
\hline City & 1.00 & - & - \\
\hline City and farm & 7.39 & 0.05 & $0.88-71.34$ \\
\hline \multicolumn{4}{|c|}{ Origin of vegetables consumed by families: } \\
\hline Farm & 1.00 & - & - \\
\hline Farm and city & 7.75 & 0.20 & $0.00-165.60$ \\
\hline
\end{tabular}

\section{DISCUSSION}

The low frequency of taeniasis infection compared to other parasitic infections is commonly observed. Licea et al. (2003) investigated cases of taeniasis and cysticercosis among food traders in a Mexican city and found 58 cases (50.4\%) of intestinal parasites by investigating for eggs, but no cases of taeniasis. Rodríguez-Hidalgo et al. (2003) were also unable to find any cases of taeniasis in an Ecuador population even though there were 30 cases $(1.55 \%)$ of other intestinal parasites identified. Ramos Jr et al. (2004) performed an epidemiological survey of cysticercosis and human taeniasis in João Costa County, Piauí, Brazil, using the same diagnostic method and identified 360 cases $(51.4 \%)$ of intestinal parasites, from which only one $(0.15)$ was taeniasis.

In Uberaba County, Minas Gerais, Brazil, Esteves et al. (2005) observed that only $185(0.2 \%)$ individuals out of 100,144 from both rural and urban areas assisted by the Family Health Program had a history of taeniasis. Among the latter, 112 (60.5\%) had been treated with anthelmintic agents, allowing for the recovery of proglottids or adult taenia from the feces of 97 patients (86.6\%), of which 36 (37.1\%) were Taenia saginata and four (4.1\%) were T. solium. Dias et al. (1991) analyzed the cases of taeniasis recorded over the length of 30 years at the Adolfo Lutz Institute in São Paulo, Brazil and observed a gradual reduction in the number of cases over time. Wandra et al. (2006) also observed a reduction in the number of cases of taeniasis in Bali, Indonesia. Based on their research, this is due to changes in raising livestock and improvements in human waste sanitation systems.

Cattle raised in extensive systems and those that drink spring water are exposed to infections transmitted by contaminated water that contains parasitic eggs. Guilherme et al. (2006) investigated the occurrence of bovine cysticercosis in Sabaudia, Paraná, Brazil and found the abovementioned risk factors in places where the infected animals were raised, thus further confirming the contamination source.

Sewage that drains into rivers from neighboring farms might contaminate the water with parasitic eggs and, thus, also contaminate the animals that consume the water along the course of the river. Rezende et al. (2006) detected cysticercosis in bovines raised in wastelands near septic tanks or open sewers with no sanitary control system in place, and they concluded that this condition might have favored animal contamination.

Consumption of well-cooked meat facilitates better control of the taeniasis/cysticercosis complex, which might explain the results of the present study, based on the dietary habits of the investigated population. Wandra et al. (2006) studied the prevalence of taeniasis by T. saginata in Bali, Indonesia and observed that all of the infected individuals consumed raw meat.

The only variable that exhibited an association with bovine cysticercosis in the present study was the consumption of meat purchased in the city and produced on the farm. This was considered a risk factor $(\mathrm{OR}=16.77)$ for taeniasis. Taking into account that there are no slaughterhouses for cattle in the county and that at all of the farms the animals 
are slaughtered without sanitary inspection, this population consumes unsupervised meat and is at risk of acquiring diseases such as taeniasis; this is a common occurrence in several Brazilian areas. According to Rezende et al. (2006), approximately $51 \%$ of the bovine meat consumed in Brazil is clandestinely obtained. These same authors assessed the occurrence of cysticercosis in bovines clandestinely slaughtered in Silva Jardim, Rio de Janeiro and found that despite the fact that $13(21.7 \%)$ out of 60 animals had the disease, their carcasses were marketed for human consumption. In visits to some of the farms investigated in the present study, these authors were able to witness the clandestine slaughter of animals and, thus, were able to establish that Viçosa harbors a factor favorable for the transmission of $T$. saginata and exposing the population to contamination.

Although the present study found a low prevalence of the taeniasis/cysticercosis complex in rural Viçosa County, constant epidemiological and sanitary surveillance is required due to the presence of one risk factor, bovine meat clandestinely obtained for consumption, recognized as favoring the disease.

Acknowledgements.- To FAPEMIG (The Minas Gerais Research Foundation) for funding the present study and to CNPq (National Council for Scientific and Technological Development) for the scholarship granted.

\section{REFERENCES}

Agapejev S. 2003. Aspectos clínico-epidemiológicos da neurocisticercose no Brasil: análise crítica. Arq. Neuropsiq. 61:822-828.

Almeida L.P., Moreira M.D., Reis D.O. \& Santos W.L.M. 2002. Cisticercose bovina: um estudo comparativo entre animais abatidos em frigoríficos com serviço de Inspeção Federal e com Inspeção Municipal. Revta. Hig. Alim. 16:51-55.

Dias R.M.D.S., Silva M.I.P.G., Mangini A.C.S., Vellosa S.A.G., Torres D.M.A.G.V., Silva R.M. \& Vaz A.J. 1991. Ocorrência de Taenia sp. na população atendida no laboratório central do Instituto Adolfo Lutz, São Paulo, SP, Brasil (1960/1989). Revta Inst. Med. Trop. 33:147-151.

Esteves F.M., Vergara M.L.S. \& Carvalho A.C.F.B. 2005. Inquérito epidemiológico sobre teníase em população do Programa Saúde da Família no Município de Uberaba. MG. Revta Soc. Bras. Med. Trop. 36:530-531.

Flisser A., Planocarte A. \& Corrêa D. 1991. Diagnóstico, tratamiento y mecanismos de evasion inmune de la cisticercosis por larvas de Taenia solium en seres humanos y cerdos. Revta Asoc. Guatemalteca Parasitol. Med. Trop. 6:43-54.

Guilherme A.L.F., Silva K., Araújo S.M., Tobias M.L. \& Falavigna D.L.M. 2006. Cisticercose em animais abatidos em Sabáudia Estado do Paraná. Arq. Bras. Med. Vet. Zootec. 58:950-951.
IBGE 2006. Censo do Instituto Brasileiro de Geografia e Estatística [Census 2006 of the Brazilian Institute of Geography and Statistics]. Available at <http://www.ibge.gov.br> Accessed Dec. 112009.

Júnior O.L.D.S. 2008. Executive Declaration of the General Coordinator of the Taxation System (Cosit) no 4, February 7, 2008. Ministry of Finance. Secretariat of the Federal Revenue of Brazil. Brasilia, 11/2/2008. Available at <http://www.receita.fazenda.gov.br/legislacao/AtosExecutivos/2008/COSIT/ADCosit004.htm> Accessed Jun. 6, 2011.

Monteiro L.L., Pinto P.S.A., Moreira M.A.S. \& Dias F.S. 2006. Diagnóstico imunológico e anátomo-patológico da cisticercose bovina. Revta Hig. Alim. 20:44-48

Pinto P.S.A., Vaz A.J., Nakamura P.M. \& Germano P.M.L. 2001. Immunoblot analisys using antigens from Taenia crassiceps cysticerci in the diagnosis of swine cysticercosis. Boln Chil. Parasitol. 56:36-42.

Ramos Jr A.N., Macedo H.W., Rodrigues M.C., Peralta R.H.S., Macedo N.A., Marques M.C., Alves J.R., Paes A.N., Castro J.A.F., Araújo A.J.G. \& Peralta J.M. 2004. Estudo soroepidemiológico da cisticercose humana em um município do Estado do Piauí, Região Nordeste do Brasil. Cad. Saúde Pública 20:1545-1555.

Rezende R.B.C., Fernadez A.T., Costa F. \& Silva T.J.P. 2006. Ocorrência de cisticercose em bovinos abatidos clandestinamente no município de Silva Jardim, RJ. Revta Hig. Alim. 21:103-109.

Rodríguez-Hidalgo R., Benítez-Ortiz W., Dorny P., Geerts S., Geysen D., Ron-Román J., Proaño-Pérez F., Chávez-Larrea M.A., Barrionuevo-Samaniego M., Celi-Erazo M., Vizcaíno-Ordóñez L. \& Brandt J. 2003. Taeniosis-cysticercosis in man and animals in the Sierra of Northern Ecuador. Vet. Parasitol. 118:51-60.

Santos V.C.R., Ramos E.T.R., Filho F.S.A., Pinto J.M.S. \& Munhoz A.D. 2008. Prevalência da cisticercose em bovinos abatidos sob Inspeção Federal no município de Jequié, Bahia, Brasil. Ciênc. Anim. Bras. 9:132-139.

Silva A.V.M. 2005. Teníase e cisticercose, p.227-237. In: Neves D.P., Linardi P.M. \& Vitor R.W.A. (Eds), Parasitologia Humana. 11aㅡ ed. Editora Atheneu, São Paulo.

Silva A.A.P. \& Silva M.V. 2007. Teníase na população do bairro Nossa Senhora Aparecida município de Correia Pinto-SC, em 2003 e 2004. Revta Bras. Anal. Clin. 39:143-145.

Souza W.K., Pessôa-Silva M.C., Minozzo J.C. \& Thomaz-Soccol V. 2007. Prevalência da cisticercose bovina no estado do Paraná, sul do Brasil: avaliação de 26.465 bovinos inspecionados no SIF 1710. Semina, Ciênc. Agrár. 28:675-684.

Takayanagui O.M. \& Leite J.P. 2001. Neurocisticercose. Revta Soc. Bras. Med. Trop. 34:283-290.

Wandra T., Sutisnac P., Dharmawand N.S., Margonoe S.S., Sudewi R., Surosoa T., Craigg P.S. \& Ito A. 2006. High prevalence of Taenia saginata taeniasis and status of Taenia solium cysticercosis in Bali, Indonesia, 2002-2004. Trans. R. Soc. Trop. Med. Hyg. 100:346-353.

WHO 2008. EPI INFO. Database and Statistics Software for Public Health Professionals. Centers for Disease Control and Prevention (CDC). World Health Organization, Geneva. Version 3.5.1. 